\title{
Removal of Dyes from the Environment by Adsorption Process
}

\author{
Massoud Kaykhaii ${ }^{1,2, *}$, Mojtaba Sasani ${ }^{3}$, Sahar Marghzari ${ }^{1}$ \\ ${ }^{1}$ Department of Chemistry, Faculty of Sciences, University of Sistan and Baluchestan, Iran \\ ${ }^{2}$ Smartphone Analytical Sensors Research Centre, University of Sistan and Baluchestan, Iran \\ ${ }^{3}$ Young Researchers and Elite Club, Zahedan Branch, Islamic Azad University, Iran
}

Copyright $\mathrm{O} 2018$ by authors, all rights reserved. Authors agree that this article remains permanently open access under the terms of the Creative Commons Attribution License 4.0 International License

\begin{abstract}
Organic dyes are considered as serious water pollutants. There are several ways for removal of these compounds from environment, which are mainly based on biological, chemical, and physical methods. In this paper, we first classify the common organic dyes which are in use in today's industry; then, methods of their elimination from environmental water and wastewater will be discussed very briefly, with an emphasize on adsorption techniques. At the end, some modern advanced adsorbents are presented.
\end{abstract}

Keywords Organic Dyes, Removal, Adsorption

\section{Introduction}

The coloring industry is a large-scale and one of the most important industries across the world. However, its wastewater in the environmental is considered as a harmful source of pollution for creatures due to variety of dyes present in it. Mutagenic and carcinogenic of some dyes have been proved [1,2]. Dysfunction of kidney, liver, brain, reproductive system and central nervous system are some effects of dyes on human being [3]. Therefore removal of dyes from environmental is of important consideration. Researchers are looking for low-cost methods to remove these dyes from the aquatic environment. It is estimated that textile industries release approximately 100 tons of dyes and pigments to the water streams annually [4-6]. Lethal dose of some dyes are collected in Table 1.

\begin{tabular}{|c|c|c|c|}
\hline & Name & $\mathrm{LD}^{50}$ (mg/Kg rat) & Source \\
\hline 1 & Malachite green & 275 & [7] \\
\hline 2 & Acid orange 165 & 60 & [8] \\
\hline 3 & Basic Blue 7 & 100 & [8] \\
\hline 4 & Basic Blue 81 & 205 & [8] \\
\hline 5 & Basic Violet 16 & 90 & [8] \\
\hline 6 & Basic Yellow 21 & 171 & [8] \\
\hline 7 & Direct Orange 62 & 150 & [8] \\
\hline
\end{tabular}

Commercial dyes can be classified according to their structure, their color and their application. Their assortment in terms of their chemical nature is presented in Table 2 [9].

Table 2. Classification of dyes based on their nature

\begin{tabular}{|c|c|c|c|}
\hline & Class & Application & Examples \\
\hline 1 & Acid dyes & $\begin{array}{c}\text { Nylon, wool, silk, } \\
\text { modified acrylics, paper, } \\
\text { leather, food, inkjet } \\
\text { printing and cosmetics. }\end{array}$ & $\begin{array}{l}\text { Acid red } 88 \\
\text { Acid red } 18\end{array}$ \\
\hline 2 & $\begin{array}{l}\text { Cationic } \\
\text { (Basic) } \\
\text { Dyes }\end{array}$ & $\begin{array}{l}\text { Poly acrylonitrile, paper, } \\
\text { modified polyesters, } \\
\text { modified nylons, cation } \\
\text { dye able polyethylene } \\
\text { terephthalate, wool, silk, } \\
\text { tannin mordanted cotton } \\
\text { and medicine. }\end{array}$ & $\begin{array}{l}\text { Crystal Violet, } \\
\text { Methylene Blue, } \\
\text { Safranin, Basic } \\
\text { fuschin }\end{array}$ \\
\hline 3 & $\begin{array}{l}\text { Disperse } \\
\text { Dyes }\end{array}$ & $\begin{array}{l}\text { Nylon, polyester, } \\
\text { cellulose, acrylic fibers } \\
\text { and cellulose acetate. }\end{array}$ & $\begin{array}{l}\text { Disperse Red 1, } \\
\text { Disperse Orange } \\
37\end{array}$ \\
\hline 4 & Direct Dyes & $\begin{array}{l}\text { Rayon and cotton, } \\
\text { leather, paper and nylon. }\end{array}$ & $\begin{array}{l}\text { Congo Red, } \\
\text { Brilliant Blue, } \\
\text { copper blue } 2 \mathrm{R}\end{array}$ \\
\hline 5 & $\begin{array}{l}\text { Reactive } \\
\text { Dyes }\end{array}$ & $\begin{array}{l}\text { Wool, nylon, cotton and } \\
\text { other cellulosic. }\end{array}$ & $\begin{array}{c}\text { Reactive Black 5, } \\
\text { Reactive Orange } \\
16\end{array}$ \\
\hline 6 & $\begin{array}{l}\text { Solvent } \\
\text { Dyes }\end{array}$ & $\begin{array}{l}\text { Gasoline, plastics, oils, } \\
\text { lubricants and waxes. }\end{array}$ & $\begin{array}{l}\text { Solvent Red 1, } \\
\text { Solvent Red 49, } \\
\text { Solvent Red 24, } \\
\text { Solvent Red 111 }\end{array}$ \\
\hline 7 & Sulfur Dyes & $\begin{array}{l}\text { Cotton and rayon, paper, } \\
\text { leather, silk and wood. }\end{array}$ & $\begin{array}{l}\text { Sulfur Brilliant } \\
\text { Green, Sulfur } \\
\text { black } 1\end{array}$ \\
\hline 8 & Vat Dyes & Cotton, rayon and wool. & $\begin{array}{l}\text { Vat red } 10 \text {, vat } \\
\text { violet } 13 \text { and vat } \\
\text { orange } 1 .\end{array}$ \\
\hline
\end{tabular}

There are a wide variety of methods to remove pollutants from environmental waters or sewage. Most of them can be classified as biological, chemical, and physical purification processes (Fig. 1) [10,11]. Of these techniques, adsorption is considered to be the most well-known process. The accumulation of adsorbates at gas-solid or liquid-solid interface is called adsorption phenomena [12]. In most cases, adsorption is reversible because of weak Van der 
Waals bonds between adsorbent and adsorbate [13]. Isotherm models are fundamental concepts that deal with adsorption science. They explain how adsorbate and adsorbent interact to each other; and also by these models, the adsorption capacity can be calculated $[14,15]$. While chemical treatments produce foul odor and byproducts, and are expensive; adsorption phenomena is of interest for dyes removal because of its low cost and flexibility in design and also because this process does not produce any harmful substances after removal of the target compounds. The most important disadvantage for biological treatment methods is that many of these processes are very time consuming. For example, mix bacteria decolorization needs up to 30 hours to be completed. On the other hand, some dyes cannot be removed by physical methods such as ion exchange; and for electrokinetic coagulation, high volume of sludge is produced. Conversely, adsorption is economical, easy to use, and can eliminate almost all type of contaminants. That's why this process is widely in use for removal of not only dyes and pigments, but also for other contaminants such as heavy metal impurities from waste water or sewage [16-22].

The first attempts for using adsorption process for removal of an unwanted compound was started in $1550 \mathrm{BC}$ by Egyptians who used charcoal to adsorb odorous vapors from wounds and intestine. Phoenicians observed the application of charcoals filters in $460 \mathrm{BC}$ purify water [12, 23]. The first article about the removal of dyes by adsorption process was published by Chapman and Siebold in 1912. In this paper, they described separation of dye molecules from water [24]. Concepts which were added in 20 century to this type of adsorbing dyes were isotherm models of adsorption, mainly by Hebert Freundlich and Irving Langmuir [25]. Also by invention of transmission electron microscopy and scanning electron microscope which were invented in 1935 we are now able to monitor the quality of adsorption [26, 27]. Nowadays a wide range of theories describe adsorption phenomena and there are a lot of practical examples, including industrial and environmental tasks that were carried out by this phenomenon. In all of them, molecular modeling plays a significant role which researchers can conjugate it with experimental techniques to achieve highest adsorption capacity.
Since adsorption deals with a lot of crucial domains such as membrane separation, chromatography and ion exchange, every development in these areas will affect tremendously on the development of new adsorption techniques.

It is obvious that the adsorption characteristics and structural adsorbents play a crucial role in using of them in various applications. Characteristics that can effect on removal of contaminations are adsorption capacity, specific surface area, pore volume, grain size and pore size distribution. They are so important because if they change, the efficiency of removal change too [28].

For the removal of dyes a wide variety of adsorbents has been used, of them, the most common are discussed below.

Zeolites are selective adsorbents which can be found in the environment and can be also synthesized in laboratory. Zeolites are highly porous and their charges are negative. Application of $3 \mathrm{~A}$ zeolite to remove Rhodamine B is common and this adsorbent can remove $\sim 90 \%$ of this contaminant from industrial wastewater [16].

Alumina is an especial crystalline gel which is synthesized in various sizes and its appearance is granule with surface area of $200-300 \mathrm{~m}^{2} \mathrm{~g}^{-1}$. Alumina is a great adsorbent for removal of disperse dyes from water [29].

Silica gel is a porous, non-crystalline granule. The surface area of it booms expeditiously rather than alumina and reaches to $900 \mathrm{~m}^{2} \cdot \mathrm{g}^{-1}$. Silica gel is prepared by the coagulation of colloidal silicic acid. A maximum adsorption capacity of $11.1 \mathrm{mg} / \mathrm{g}$ for modified silica gel was reported for removal of sulfur dyes from aqueous solutions [30].

Activated carbon is the oldest well-known adsorbent and it usually is prepared from coconut shell, lignite, wood, coal, and so on. Since commercial activated carbon for dye removal is expensive, some adsorbents which special features like eco-friendly and environmental friendly have been used There are numerous articles about removing of dyes and other pollutants by activated carbon. Furthermore, surface area in activated carbon is quite high (near 200 $\left.\mathrm{m}^{2} \cdot \mathrm{g}^{-1}\right)[31,32]$. Despite that this adsorbent is very effective, it is not selective.

It is ideal for all of the adsorbents to be regenerated after being used and became saturated. Various techniques such as electrochemical, thermal, chemical methods and ultrasonic were reported for this purpose [33]. 


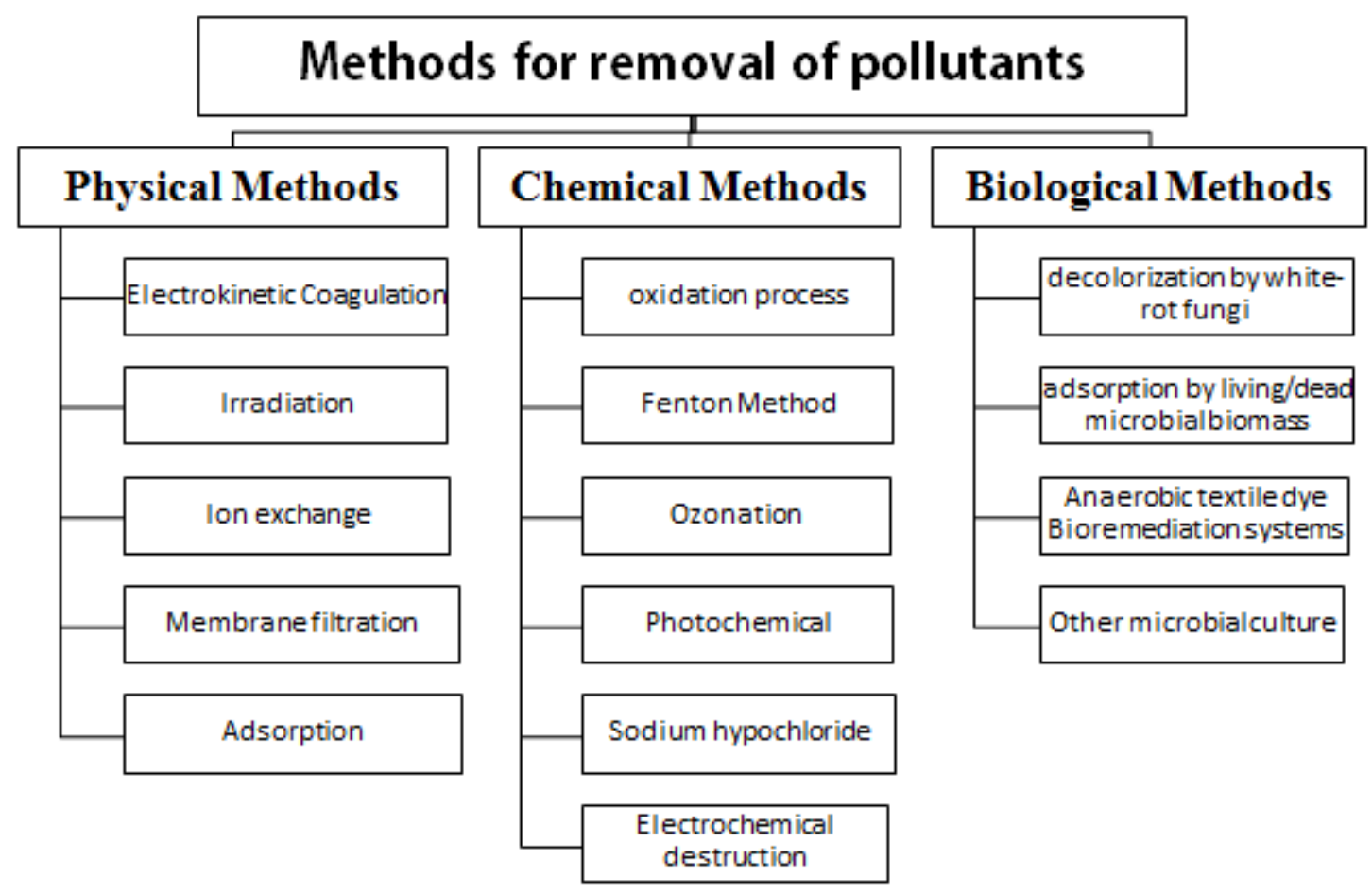

Figure. 1. Methods generally in use for removal of pollutants

Occasionally, some adsorbents are disposed after using because they cannot be regenerated and consequently they became secondary pollutants. Researchers try to make some new adsorbents with high surface area to solve this problem. Recently, many papers have been published that show there is a tendency to synthesize high surface area materials such as modified silica and zeolites; $\mathrm{ZnO}$ and $\mathrm{TiO}_{2}$ on clay; metal-organic frameworks; carbon nanocages; graphene; nanotubes; porous polymers and functional $3 \mathrm{D}$ boron nitride nanostructures to remove dyestuffs from water [34-40]. Not only the most of these adsorbents can be reused, but they are very efficient and fast, thanks to their high surface area.

It is anticipated that over the next 10 years the developing and investigating of new adsorbents with super adsorption capacity will be more rapid and novel adsorbents will be tested to solve pollution problem to some extent. Just as an example, super adsorbents polymers (SAPs), which are the 3 dimensional networks of polymers, can adsorb more than 100 times of liquid of their own weight. Since SAPs possess ionic groups in 3 demonstrate networks, they adsorb oppositely charged materials [41]. Form these characteristic, researchers can provide and achieve selective super adsorbents.

\section{Conclusions}

Urbanization has left some negative effects on environment such as releasing dyes to water streams. Since organic dyes are carcinogenic and mutagenic, researchers are trying to find some methods to remove this pollution from water/wastewater. Adsorption is an economical and simple method for this purpose. We reviewed some common adsorption techniques in this manuscript. Some modern adsorbents which are expected to be in use in the future are also presented. They have the ability to be re-generated and possess extremely high surface area.

\section{REFERENCES}

[1] K. Golka, S. Kopps, Z.W. Myslak, Carcinogenicity of azo colorants: influence of solubility and bioavailability, Toxicology letters, 151 (2004) 203-210.

[2] S. Shojaei, S. Khammarnia, S. Shojaei, M. Sasani, Removal of reactive red 198 by nanoparticle zero valent iron in the presence of hydrogen peroxide, journal of water and environmental nanotechnology, 2 (2017) 129-135.

[3] K. Kadirvelu, M. Kavipriya, C. Karthika, M. Radhika, N. Vennilamani, S. Pattabhi, Utilization of various agricultural wastes for activated carbon preparation and application for the removal of dyes and metal ions from aqueous solutions, Bioresource technology, 87 (2003) 129-132.

[4] M. Rahmani, M. Kaykhaii, M. Sasani, Application of Taguchi L16 design method for comparative study of ability of 3A zeolite in removal of Rhodamine B and Malachite green from environmental water samples, Spectrochimica Acta Part A: Molecular and Biomolecular Spectroscopy, 188 (2018) 164-169.

[5] S. De Gisi, G. Lofrano, M. Grassi, M. Notarnicola, Characteristics and adsorption capacities of low-cost 
sorbents for wastewater treatment: A review, Sustainable Materials and Technologies, 9 (2016) 10-40.

[6] M.T. Yagub, T.K. Sen, S. Afroze, H.M. Ang, Dye and its removal from aqueous solution by adsorption: a review, Advances in colloid and interface science, 209 (2014) 172-184.

[7] S. Cleinmensen, J.C. Jensen, N.J. Jensen, O. Meyer, P. Olsen, G. Würtzen, Toxicological studies on malachite green: a triphenylmethane dye, Archives of toxicology, 56 (1984) 43-45.

[8] R. Anliker, G. Duerig, D. Steinle, E. Moriconi, List of colorants to be classified as toxic, Journal of the Society of Dyers and Colourists, 104 (1988) 223-225.

[9] V.K. Gupta, Suhas, Application of low-cost adsorbents for dye removal - A review, Journal of Environmental Management, 90 (2009) 2313-2342.

[10] C.R. Holkar, A.J. Jadhav, D.V. Pinjari, N.M. Mahamuni, A.B. Pandit, A critical review on textile wastewater treatments: possible approaches, Journal of environmental management, 182 (2016) 351-366.

[11] Z. Aksu, Application of biosorption for the removal of organic pollutants: a review, Process Biochemistry, 40 (2005) 997-1026.

[12] A. Dabrowski, Adsorption - from theory to practice, Advances in Colloid and Interface Science, 93 (2001) 135-224.

[13] S. Allen, B. Koumanova, Decolourisation of water/wastewater using adsorption, Journal of the University of Chemical Technology and Metallurgy, 40 (2005) 175-192.

[14] A. Srinivasan, T. Viraraghavan, Decolorization of dye wastewaters by biosorbents: a review, Journal of environmental management, 91 (2010) 1915-1929.

[15] N.N. Nia, M. Rahmani, M. Kaykhaii, M. Sasani, Evaluation of Eucalyptus leaves as an adsorbent for decolorization of Methyl Violet (2B) dye in contaminated waters: Thermodynamic and Kinetics model, Modeling Earth Systems and Environment, 3 (2017) 825-829.

[16] M. Rahmani, M. Sasani, Evaluation of $3 \mathrm{~A}$ zeolite as an adsorbent for the decolorization of rhodamine $\mathrm{B}$ dye in contaminated waters, Applied Chemistry, 11 (2016) 83-90.

[17] H.A. Hegazi, Removal of heavy metals from wastewater using agricultural and industrial wastes as adsorbents, HBRC Journal, 9 (2013) 276-282.

[18] A. Javaid, R. Bajwa, U. Shafique, J. Anwar, Removal of heavy metals by adsorption on Pleurotus ostreatus, Biomass and Bioenergy, 35 (2011) 1675-1682.

[19] S. Mondal, Methods of dye removal from dye house effluent-an overview, Environmental Engineering Science, 25 (2008) 383-396.

[20] M.A.M. Salleh, D.K. Mahmoud, W.A.W.A. Karim, A. Idris, Cationic and anionic dye adsorption by agricultural solid wastes: A comprehensive review, Desalination, 280 (2011) 1-13.

[21] R. Alizadeh, R. Kazemi, M. Rezaei, Ultrafast removal of heavy metals by tin oxide nanowires as new adsorbents in solid-phase extraction technique, International Journal of Environmental Science and Technology, 15 (2018) 1641-1648.

[22] J. Acharya, U. Kumar, P.M. Rafi, Removal of Heavy Metal Ions from Wastewater by Chemically Modified Agricultural Waste Material as Potential Adsorbent-A Review, (2018).

[23] E. Robens, S.A.A. Jayaweera, Early History of Adsorption Measurements, Adsorption Science \& Technology, 32 (2014) 425-442.

[24] A.C. Chapman, A. Siebold, on the application of adsorption to the detection and separation of certain dyes, Analyst, 37 (1912) 339-345.

[25] I. Langmuir, The adsorption of gases on plane surfaces of glass, mica and platinum, Journal of the American Chemical Society, 40 (1918) 1361-1403.

[26] D. McMullan, Scanning electron microscopy 1928-1965, Scanning, 17 (1995) 175-185.

[27] D.B. Williams, C.B. Carter, The transmission electron microscope, in: Transmission electron microscopy, Springer, 1996, pp. 3-17.

[28] J. Rouquerol, F. Rouquerol, P. Llewellyn, G. Maurin, K.S. Sing, Adsorption by powders and porous solids: principles, methodology and applications, Academic press, 2013

[29] B. Shi, G. Li, D. Wang, C. Feng, H. Tang, Removal of direct dyes by coagulation: The performance of preformed polymeric aluminum species, Journal of Hazardous Materials, 143 (2007) 567-574.

[30] J. Lin, J.A. Siddiqui, R.M. Ottenbrite, Surface modification of inorganic oxide particles with silane coupling agent and organic dyes, Polymers for Advanced Technologies, 12 (2001) 285-292.

[31] N.F. Cardoso, E.C. Lima, B. Royer, M.V. Bach, G.L. Dotto, L.A. Pinto, T. Calvete, Comparison of Spirulina platensis microalgae and commercial activated carbon as adsorbents for the removal of Reactive Red 120 dye from aqueous effluents, Journal of hazardous materials, 241 (2012) 146-153.

[32] Z. Hu, M.P. Srinivasan, Mesoporous high-surface-area activated carbon, Microporous and Mesoporous Materials, 43 (2001) 267-275.

[33] S. Natarajan, H.C. Bajaj, R.J. Tayade, Recent advances based on the synergetic effect of adsorption for removal of dyes from waste water using photocatalytic process, Journal of Environmental Sciences, (2017).

[34] P. Sharma, H. Kaur, M. Sharma, V. Sahore, A review on applicability of naturally available adsorbents for the removal of hazardous dyes from aqueous waste, Environmental monitoring and assessment, 183 (2011) 151-195.

[35] Y. Zhi, Y. Li, Q. Zhang, H. Wang, ZnO nanoparticles immobilized on flaky layered double hydroxides as photocatalysts with enhanced adsorptivity for removal of acid red G, Langmuir, 26 (2010) 15546-15553.

[36] E. Seftel, M. Niarchos, C. Mitropoulos, M. Mertens, E. 
Vansant, P. Cool, Photocatalytic removal of phenol and methylene-blue in aqueous media using $\mathrm{TiO}_{2} @ \mathrm{LDH}$ clay nanocomposites, Catalysis Today, 252 (2015) 120-127.

[37] X. Zhao, S. Liu, Z. Tang, H. Niu, Y. Cai, W. Meng, F. Wu, J.P. Giesy, Synthesis of magnetic metal-organic framework (MOF) for efficient removal of organic dyes from water, Scientific reports, 5 (2015) 11849.

[38] Z. Zhu, Y.-L. Bai, L. Zhang, D. Sun, J. Fang, S. Zhu, Two nanocage anionic metal-organic frameworks with rht topology and $\left\{\left[\mathrm{M}\left(\mathrm{H}_{2} \mathrm{O}\right) 6\right] 6\right\} 12+$ charge aggregation for rapid and selective adsorption of cationic dyes, Chemical Communications, 50 (2014) 14674-14677.
[39] M. Yusuf, F. Elfghi, S.A. Zaidi, E. Abdullah, M.A. Khan, Applications of graphene and its derivatives as an adsorbent for heavy metal and dye removal: a systematic and comprehensive overview, RSC Advances, 5 (2015) 50392-50420.

[40] D. Liu, W. Lei, S. Qin, Y. Chen, Template-free synthesis of functional 3D BN architecture for removal of dyes from water, Scientific reports, 4 (2014) 4453.

[41] L.P. Esteves, Superabsorbent polymers: On their interaction with water and pore fluid, Cement and Concrete Composites, 33 (2011) 717-724. 